\title{
Robespierre, Old Regime Feminist? Gender, the Late Eighteenth Century, and the French Revolution Revisited*
}

\author{
Alyssa Goldstein Sepinwall \\ California State University, San Marcos
}

It has become a commonplace of scholarship on the French Revolution that the Jacobins sought to exclude women from political and intellectual life. Even as recent work has noted that the Revolution improved women's status in areas such as divorce, 'the enduring image of the Jacobins' attitude toward gender is their dismissal of women's intellectual abilities and their emphasis on mothering roles. Histories of the Revolution often include the claim made by the deputy Amar during the debate on women's political clubs that women were "ill-suited for elevated thoughts and serious meditations." 2 Scholars generally depict this declaration either as emblematic of Jacobin misogyny or as representing the simple continuation of eighteenth-century prejudices about women, whether derived from Christianity or Rousseauism. Against Rousseau and his followers, Condorcet has loomed as an isolated male feminist of the era for his support of expanded opportunities for women. ${ }^{3}$

* I am deeply indebted to Jean-Éric lung, director of the Archives départementales du Pas-de-Calais, and to Michel Beirnaert and the late Léon Berthe of the Archives historiques diocésaines of Arras for allowing me to consult the sources used in this essay; also to Jennifer Heuer for the multiple ways in which she improved my analysis of this material. I am also grateful to Dena Goodman, Paula Findlen, Karen Offen, Margaret Jacob, Jeremy Caradonna, Laura Mason, Dominique Rogers, and Joe Zizek for suggestions during my research, and to Marisa Linton, Keith Michacl Baker, Mary Louise Roberts, Suzanne Desan, Lynn Hunt, Lisa Moses Leff, Kent Wright, Kathleen Wellman, Mita Choudhury, Jeremy Popkin, Dale Van Kley, and Julia Landweber for their comments on earlier drafts of this article.

' See esp. Suzanne Desan, The Family' on Trial in Revolutionary France (Berkeley, 2004); Carla Hesse, The Other Enlightenmen: How French Women Became Modern (Princeton, NJ, 200I); and Jennifer Heuer, The Family and the Nalion: Gender and Citizenship in Revolutionary France, $1789-1830$ (Ithaca, NY, 2005).

${ }^{2}$ See Archives Parlementaires de 1787 à 1860, le séric (Paris, 1879-1913) (hereafter $A P$ ), 78 (9 brumaire II/ October 30, 1793), 49-51: translation from Darline Gay Levy and Harriet B. Applewhite, "Women and Mititant Citizenship in Revolutionary Paris," in Rebel Daughers: Women and the French Rerolution. ed. Salla E. Melzer and Leslie W. Rabine (New York, 1992), 96.

"I am using the term "feminism" here in a limited sense, following early modern scholars such as Carolyn Lougee. Though "the term did not exist in the period" and "readers may unwittingly alssociate with the term connolations foreign to the seventeenth-century mentality," Lougee argues that it is a useful "shorthand" to denote

The Joumal of Modern Histery 82 (March 2010): 1-29

(1) 2010 by The Universily of Chicago. $0022-2801 / 2010 / 8201-000151000$

All righis reserved.

This content downloaded from 144.037.178.082 un April (03.2017 13:09:29 PM

All use subject to Universily of Chicago Press Terms and (onditions (hup://wiww.journals.uchicago.edu/l-and-c). 


\section{Sepinwall}

For some Jacobins, however, arguments about women's inferiorily may not have been an inevitable outgrowth of Old Regime views, but rather a retreat from their previous positions. This article will focus on the case of a young Arras lawyer, a certain Maximilien Robespierre, who argued for the admission of women to royal academies in 1787. Though Robespierre's discourse on the subject has been almost entirely ignored in modern scholarship, ${ }^{4}$ at the time it attracted praise and condemnation from around the country. Using archival materials from the Academy of Arras and additional sources published by the historian Léon Berthe, ${ }^{5}$ I will focus on the academy's admission of two

\footnotetext{
"the positive response to the question whether women should play a public role in French society." See Carolyn C. Lougee, Le paradis des femmes: Women, Salons, and Social Stratification in Sevenleenth-Century France (Princeton, NJ, 1976), 7; also Erica Harth, Cartesian Women: Versions and Subversions of Rational Discourse in the Old Regime (Ithaca, NY, 1992), 215.

${ }^{4}$ Because of the intense interest among French scholars and collectors in anything remotely related to Robespierre, perhaps no text authored by him is completely unknown. Versions of the speech have been reprinted at various times, such as in $\mathrm{H}$. Duval, "Robespierre et l'admission des femmes," Revue historique de la Révolution française 5 (1914): 324-26; Léon Berthe, "Un inédit de Robespierre: Sa réponse au discours de réception de Mademoiselle de Kéralio-18 avril 1787," Ammales historiques de la révolution française 46 (1974): 261-83; and most recently Florence Gauthier, ed., Oeuvres de Maximilien Robespierre, Tome XI: Compléments (17841794) (Paris, 2007), 185-201. Biographers of Robespierre occasionally mention the speech while discussing his youth (e.g., J. M. Thompson, Robespierre [New York, 1936], 1:21-22). American historians of gender and of the Revolution, however, do not seem aware of it; and though French scholars of Robespierre may know about the speech, its implications have remained outside their interests. Berthe's analysis of the speech was pioneering but has had no impact on revolutionary gender historiography. Gauthier's introduction to Robespierre's speech makes a number of valuable observations, such as noting the gallantry of Robespierre's language and its similarity to some of that of Poullain de la Barre; still, it offers only a brief analysis of the speech.

${ }^{5}$ Berthe had full access to the papers of Dubois de Fosseux, the Arras Academy's perpetual secretary, when they were held privately; his research on Robespierre's speech was published in his "Un inédit de Robespierre"; his Dubois de Fosseux, secréraire de l'Académie d'Arras, 1785-1792 et son bureau de correspondance (Arras, 1969); and his Dictionnaire des correspondants de l'Académie d'Arras au temps de Robespierre (Arras, 1969). Though Dubois de Fosseux's papers are now conserved in the Archives départementales du Pas-de-Calais (hereafter ADPC), the collection is still owned by his descendants, and the loan to the state archives has especially strict conditions. The collection has no public inventory, and documents must be requested by author and date. What this means essentially is that scholars can only request those documents that Berthe previously referenced. While my analysis here goes beyond Berthe's (which was written before the last three decades of scholarship on gender and the Revolution and therefore did not raise the kinds of questions I pose here), I am nonetheless greatly indebted to his work.
} 
women members in 1787, Robespierre's enthusiastic support of this decision, and the subsequent debate that Robespierre's views aroused.

The Arras debate has much to teach us about gender ideas in the late Old Regime and the French Revolution. First, it offers a fascinating window into ideas about gender and science in the Old Regime's final years. It shows the extent to which women's potential as scholars was accepted and in what terms it was contested. In particular, it demonstrates that biomedical views defining women as naturally inferior had not yet become ascendant by the 1780s. Initiatives by the Arras Academy and others also show that the public sphere was beginning to offer new opportunities for women, just before the turbulence of the Revolution altered the terrain of gender. The Arras debate also provides a startling glimpse of young Robespierre, reminding us that Condorcet was not alone in seeing women as unjustly treated.

No less importantly, the Arras debate invites a reconsideration of the Revolution's later actions regarding women. Revolutionary discussions of women in fact show a greater persistence of Cartesian views than has generally been acknowledged; multiple discourses on women endured into the Revolution, with biological ones triumphing only after late 1793. Indeed, as I hope to show, even Rousseauism did not automatically entail efforts to exclude women; Rousseau's admirers did not necessarily support all of his views on gender. Viewing revolutionary discussions of women as extensions of the debates of the 1780s helps us see just how contingent the exclusion of women and the rise of "separate spheres" ideology were.

The Arras Academy, the center of our story, was one node in a larger academic system, a crucial element of the eighteenth-century republic of letters both in France and in Europe more generally. In contrast to salons, which have received more attention in recent years, academies were official royal bodies. As James McClellan has noted, the title of academician was highly sought after, since the holder attained a "distinct and formal place" in the monarchy. Also in contrast to most salons, academies were male spaces. Though the regulations of French academies did not forbid admitting women, in practice women were almost never made members. ${ }^{6}$ As Mary Terrall has noted in regard to the Parisian Academy of Sciences, public meetings of academies were sometimes open to both sexes, and aristocratic women "served as prestigious admirers and spectators whose attention valiclated the scientific enterprise." Nevertheless, the inner sanctum of the Academy of Sciences, like nearly all academies, remained exclusively male. ${ }^{7}$

"See James E. McClellan, Science Reorganized: Scientific Societies in the Eighreenth Century (New York, 1985), 234ff.; Londa L. Schjebinger, The Mind Has No Sex? Women in the Origins of Modern Science (Cambridge, MA, 1989), 23ff.: and Daniel Roche, Le siècle des lumières en province (Paris, 1978).

${ }^{7}$ Mary Terrall, "Metaphysics, Mathematics, and the Gendering of Science in 


\section{Sepinwall}

Some exceptions existed. In Italy, a handful of women such as Laura Bassi were admitted to academies from early in the eighteenth century, though they were still spoken of in gendered terms. ${ }^{8}$ In France, the three main Parisian academies refused entry to women, but some provincial academies did elect isolated women, such as Mme de Houlières in Arles in the 1680s and Mme du Bocage in both Lyon and Rouen in the 1750s. ${ }^{9}$ John Iverson, Marie-Pascale Pieretti, and Jeremy Caradonna have also shown that women entered-and were able to win-academy prize contests. In many cases, they were able to do so because the traditional anonymity of submissions concealed their gender; in others, as Caradonna has found, women were awarded prizes even after referring to their gender in their entries. ${ }^{10}$ Efforts to include women had the intellectual support of Cartesians inspired by François Poullain de la Barre (1647-1723), who had argued in 1673 that men's and women's brains did not differ and that what was viewed as "women's nature" was simply a product of history and socialization."

While the inclusion of women in the academic system was episodic, I will argue that by the 1780 s there was a nascent movement to make it more

Eighteenth-Century France," in The Sciences in Enlightened Europe, ed. William Clark, Jan Golinski, and Simon Schaffer (Chicago, 1999), 247. As Poullain de la Barre himself noted in 1673, "[Men] founded Academies to which women were not invited; and in this way [women] were excluded from learning as they were from everything else" (cited in Paula Findlen, "Science as a Career in Enlightenment Italy: The Strategies of Laura Bussi," Isis 84, no. 3 [1993]: 444). Ironically, as Kathleen Wellman has noted, salonnières often exercised influence "behind the scenes" in selecting academicians (Making Science Social: The Conferences of Théophraste Renaudot, 1633-1642 [Norman, OK, 2003], 347), though they could not be admitted themselves.

"Sec Findlen, "Science as a Career," as well as her other articles, such as "A Forgotten Newtonian: Women and Science in the Italian Provinces," in The Sciences in Enlightened Europe, ed. Clark et al., 313-49, and "The Scientist's Body: The Nature of a Woman Philosopher in Enlightenment Italy," in The Faces of Nature in Enlightenment Europe, ed. Lorraine Daston and Gianna Pomata (Berlin, 2003), 211-36.

"While a full list does not yet exist, some académiciennes are named in Francisque Bouillier, L'Institut e' les académies de province (Paris, 1879), 85; and Berthe, "Un inédil de Robespictre," 271.

10 John Iverson and Maric-Pascale Pieretti, "'Toutes personnes [. . .] seront admises a concourir": Lal participation des femmes aux concours académiques," Dix-huitième siècle $36(2004)$ : 312-32: and Jeremy Caradonna, "The Enlightenment in Question: Prize Contests and the Francophone Republic of Letters, 1670-1794" (PhD diss., Johns Hopkins University, 2007), chap. 3 and App. A.

"Sce esp. Sicp Suurman, François Poulain de la Barre and the Invention of Modern Equality (Cambridge, MA, 2004), I14ff. On Cartesian and neo-Platonic discourses on women in the period more generally, see Denat Goodman, "Women and the Enlightenment," in Becoming Visible: Women in European History, ed. Renate Bridenthal, Susin Mosher Stuard, and Merry E. Wiesner (Boston, 1998), 233-62. 
regular. The Royal Academy of Belles-Lettres of Arras was a center of this effort. The Arras Academy was traditionally not one of France's most important academies, and it is not a place from which we might at first expect to see a transformation in the academy. Daniel Roche classifies it as having been in the third tier of French academies, after those in major provincial cities such as Bordeaux and those in important regional capitals such as Metz. However, as Berthe emphasized in the 1960s, its importance grew after the appointment in 1786 of Ferdinand Dubois de Fosseux (1742-1817) as its sécretaire perpétuel. Dubois de Fosseux, a progressive-minded aristocrat who had spent many years at Versailles, engaged in many initiatives to raise the Arras Academy's profile. The most important of these was his creation of a bureau de correspondance, which sought to bring the academies and intellectuals of France together in regular contact, an unprecedented undertaking. Roche called Dubois's achievement in creating this network "extraordinary," while McClellan has noted that it marked "at last, ... the emergence of a national organization for science in France."'12

Dubois also made the inclusion of women a hallmark of his stewardship of the Arras Academy. Even before becoming perpetual secretary, he had been using his annual member's discourse to speak about issues related to women's education. In 1786, as he scanned French newspapers for up-and-coming writers to include in his correspondence network, he began to correspond with Olympe de Gouges. And when the academy decided in 1787 to create a class of honorary members, allowing prominent intellectuals who resided outside of Arras to join the academy, Dubois led his members in deciding to include two well-known women, the historian Louise de Kéralio (from Paris; 1758-1821) and the scientist Marie LeMasson-LeGolft (from Le Havre; 1749-1826), on the inaugural list of fifteen honoraries. These women, alongside male scholars such as the Saint-Domingue lawyer Moreau de Saint-Méry, were elected from a group of thirly-nine candidates. ${ }^{13}$

Upon election, members were expected to deliver a discours de réception, to which the academy offered an official response. This is where Robespierre enters our story. The young lawyer, who had been making a name for himself in Arras and throughout the country, had been elected a member of the

1. See Roche, Le siecle des lumières en province, 1:89, 69; Berthe, Dubois de Fosseur: and McClellan, Science Reorganized, 185-86.

1.3 See Berthe, "Un inédil de Robespierre," 272ff; Berthe, Dubois de Fosseux, 151, 176: and Berthe, Dictionnaire des correspondants, 108. LeMasson-LeGolft had already been elected to the Cercle des Philadelphes, the scholarly society in SaintDomingue, though that body docs not seem to have been making a statement about gender. Her correspondence with that acalemy is conserved in the Bibliothèque municipal de Rouen (hereafter BMR), ms. g. 15 (63), fols. 79-279. 


\section{Sepinwall}

academy in 1783 and a director in $1786 . .^{14}$ Though he was absent from the meeting at which Kéralio and LeMasson-LeGolft were elevated to membership, he subsequently wrote the response to Kéralio's discours de réception, and in doing so advocated the inclusion of women in academies as a general principle.

At first approach, Rohespierre's response may appear to have been a nonevent, especially based on its most commonly available version. The future Jacobin did not make totalizing claims about men's and women's equality, and he spoke of men and women as being inherently different, as having received different sets of talents from nature and as having separate kinds of social responsibilities. He described "strength and profundity" as "characteriz[ing] the genius of men" and "delicacy and being pleasing" as "distinguish[ing] that of woman." Aspects of his discussion can be read as condescendingly gallant, full of references to how women's "charms" would make meetings more fun to attend and inspire men to want to achieve ever greater deeds in order to impress women. "Encouraging talents is one of women's foremost duties," he proclaimed. Moreover, since women are the most interesting half of humanity in men's eyes, "the love of glory has as its main goal gaining their approval."15

Such language might lead one to surmise that Robespierre was not truly committed to women's inclusion and that he had been forced to defend the decision retroactively, out of deference to his academy confreres. There are two problems with this notion, however. Though the academy admitted women at a meeting from which Robespierre was absent, it was not a foregone conclusion that he would support the decision, much less opt to write a discourse praising it as a general rule. For one thing, Robespierre was by this time a rather delinquent academy officer. Berthe has noted that the future Jacobin, busy with his law career and his own writing, often shirked his academy duties, attending only one in three meetings. By spring 1787 , he was near the end of his one-year term as director and had wearied of colleagues he viewed as overly traditionalist. Indeed, according to Berthe, he often exasperated Dubois by avoiding tasks that Dubois assigned to him. Still, even if Robespierre had felt compelled to follow Dubois's instructions faithfully, a general discourse regarding women was not part of his charge. Dubois asked him only to respond to the reception discourses of three new male honoraries

It See Berthe, Dubois de Fosserix, 120, 146.

15 See H. Duval, "Robespierre et l"admission des femmes," 324-26. This version of the speech is reprinted from [Robespierre], "Des avantages de l'admission des femmes dans les Sociétés Littéraires," La nature considérée sous ses différens aspects, ou Jounal d'histoire nuturelle 3 (1787): 417-20. With the exception of two additional paragraphs at the beginning actually althored by Dubois de Fosseux (see Berthe, "Un inédit de Robespierre," 264), this text is the same als the one that the acialemy published at the time in Extrait des deur séances publiques de l'Académie royale des BellesLetrres d'Arras tenues le 18 arril et le 25 mai 1787 ([Arras], [1787]), 14-18. 
and Mlle de Kéralio. ${ }^{16}$ Her discourse, in contrast to that of LeMasson-LeGolft, made no specific reference to gender. ${ }^{17}$ Robespierre needed only to praise the incoming members for their specific talents. Instead, he chose this opportunity to make a general declaration about the inclusion of women in the republic of letters.

The second problem with focusing on the gallantry of the speech is evident if we examine its fullest version, published by Berthe in 1974. In this version, Robespierre offered a much stronger argument for including women than simply saying they would make meetings more enjoyable; he revealed a true passion for the cause. In fact, many of his arguments prefigure similar ones that would be made by Condorcet later that year and in $1790 .{ }^{18}$ Robespierre began by condemning the fact that académiciennes were so rare in France, complaining that "the admission of a woman in a literary society has been regarded until now as a veritable phenomenon. France, and the whole of

${ }^{16}$ See Berthe, "Un inédit de Robespierre," 263-64, 267; and Berthe, Dubois de Fosseux, 202. Dubois's only specific request was that Robespierte attend first to welcoming one of the new male members, $M$. de Courset.

${ }^{17}$ Berthe makes no mention of LeMasson-LeGolft's discours de réception, and Gauthier was unaware of its existence (Oeuvres de Robespierre, 189 n. 3). The available LeMasson-LeGolft materials in the ADPC include only informal thanks to Dubois and the academy (LeMasson-LeGolft to Dubois, February 13, 1787, and LeMasson-LeGolft to the academy, February 13, 1787 [cote provisoire for all LeMasson-LeGolft materials, 32 J 345, doss. 685]). Unlike Kéralio, who came from a literary family, LeMasson-LeGolft, the daughter of a ship's captain, did not realize that she needed to write a formal discourse until Dubois told her that it was expected (Dubois to LeMasson-LeGolft, février 4, 1787, in BMR, fonds LeMasson-LeGolft, ms. g. 15 [63], fol. 149). While it may not have been sent, LeMasson-LeGolft's papers do contain an eloquent final version (BMR, ms. g. 15 [6.3], fol. 147 ["Copie du discours ou plutôt remerciment de Mlle Le Masson Le Golft à l'Académie Rale des B-Lettres d'Arras..."], undated). A letter in Dubois de Fosseux's papers suggests that LeMasson-LeGolft did send it; it refers to an enclosed discourse while noting that "if it does not fulfill all that one expected of it, please recognize, Monsieur, that it is for me something new" (LeMasson-LeGolft to Dubois, March 10, 1787, ADPC, cote provisoire $32 \mathrm{~J} 345$, doss. 685).

${ }^{18}$ See Condorcet, "On the Admission of Women to the Rights of Citizenship" (1790), in Condorcet: Selected Writings, cd. Keith Michacl Baker (Indianapolis, 1976), 97-104 (esp. Condorcet's references to women's having the same rights as men to develop their intellects, and to the "power of habit" in denying them this right). Condorcet spoke a language of complementarity analogous to Robespierre's; while speaking of women's rights, he also referred to their "charms" and their differences, seeing them as "superior to men in the gentle and domestic virtues" but inferior in their "mental and physical powers" ("On the Admission," 101). In his 1787 Lellres d'un bourgeois de New Haven, Condorcet similarly complained about the effects of custom in stifling women's intellectual development and consequently the advancement of society (Oeurres de Condorcet, ed. A. Condorcet O'Connor and M. F. Arago [Paris, [847], 9:19),

This content downloaded from 144.037.178.082 on April 03. 2017 13:09:29 PM

All use subject to University of Chicago Press Terms and Conditions (hutp://www.journals uchicago.edu/t-and-c). 


\section{Sepinwall}

Europe, offer very few such examples." To him, this was a great error that needed to be corrected; he argued that "habit and perhaps the force of prejudice" had intimidated women from presenting themselves as candidates for open academy positions. But such prejudices needed to be eradicated. "Their sex does not make them lose the rights that their merit has earned them." "Prejudices are the scourge of the world."19

Second, Robespierre insisted that, as intelligent beings, women had the right to develop their intellects: "No one will ever persuade the universe that an intelligent being cannot perfect its reason [and] extend the limits of its intelligence. ... But if we grant that women have reason and intelligence, can we refuse them the right of cultivating them?" As a believer in gender complementarity, Robespierre did not feel that women and men should study the same subjects; he called women the more delicate and sensible sex and said that men were more suited to study "ihe intricacies of the abstract sciences." Nevertheless, he insisted, this did not mean that women should not be permitted to contribute to those fields that "demand only sensibility and imagination," such as literature, history, and morality. ${ }^{20}$

Robespierre made it clear that his convictions on the matler were even stronger than those of his fellow members who had elected Kéralio and LeMasson-LeGolft. He applauded them for the courage they had shown in "rising against a vulgar prejudice." Nevertheless, he criticized them for not going farther. In creating a class of honorary nonresident members who were not ever obligated to attend meetings in person, the academy was losing the benefit of including them. He felt that women members' altendance, even if occasional, was vital:

The choice that you have made leaves ... our system very imperfect. Whatever be the merit of our honorary académiciennes, they will always have one essential shortcoming: that is to be distanced from us, to never give us the advantage of embellishing our ussemblies with their presence.

We read them, we hear their words, we speak to them, but we never see them. . . To attain the goal I have discussed, we need to go further ... . we need to include even more of our concitoyennes in the Academy.

Robespierre insisted that women drove progress and that their presence was necessary for enlightenment to spread: "the lumière of letters has begun to

19 See Léon Berthe, ed., "Réponse de Maximilien de Robespierre, avocat au Parlement et directeur de l'Académie, au discours de Mademoiselle de Kéralio," Annales hisıriques de la révolution française 46 (1974): 274-83 (which follows Berthe's introductory article, "Un inédit de Robespierre," 261-73). Quotations in this paragraph are from 274-76. Berthe located this manuscript (a copy made by Dubois de Fosseux"s secretary from Robespierre's original, which appears to be lost) in the privalte collection of a Dr. Michel de Langre; as far as I am aware, it remains in private hands.

20) Ibid., 276. 
reappear [after the Middle Ages], and it is women who will accelerate the happy revolution that will be the result." Far from insisting that women had a separate nature that necessitated their exclusion from such gatherings, Robespierre felt that the "travails of the human mind" would be perfected by bringing together men's and women's different qualities, and that the "way to do this is by adding women to literary societies." ${ }^{21}$ Here, Robespierre was taking the opposite position from that of Rousseau. ${ }^{22}$

Finally, Robespierre declared that his position was firmly grounded in his own philosophical convictions and that it was based neither on politeness to women nor on letting their beauty eclipse his reason. Lamenting that "an opinion favorable to women is often suspect," he insisted that "if one goes so far as to suspect me of sacrificing interest in the truth for considerations of another type, one would be mistaken." He also declared that the same was true for his confreres: "May no one believe that, in adopting this innovation, the Academy was driven by frivolous sentiment: the decision was based on wise and profound views." Insisting that he had been neither "swept up by blind enthusiasm" nor in the thralls of a "seductive prejudice," he argued that just because something was agreeable did not mean it was not eminently rational. Prejudices against women, he proclaimed, were the "scandal of an enlightened century"; he urged other academies to follow Arras's example. ${ }^{23}$

Though Robespierre's language did not proceed from the same premises as modern feminism, resting instead on ideas of complementarity, his convic-

${ }^{21}$ Ibid., 275, 282, 280-81, 276. For a "striking but unusual" precursor of this position, see the speaker in Renaudot's conferences (1636) who supported women's work in the sciences, even if not proposing their integration into academies: "If women joined together with men in the discovery of those parts [of science that remain unknown], who doubts but that feminine curiosity would serve to sharpen the point of men's wits, distracted by extraneous affairs, and make marvelous progress and discover rare secrets, thus far unknown" (Wellman, Making Science Social, 358-59).

${ }^{22}$ Rousseauls valorization of male-only gatherings is perhaps best expressed in Politics and the Arts, Letter to $M$. d'Alembert on the Thearre, trans. Allan Bloom (Glencoe, IL, 1960), 105: "By themselves, the men, exempted from having to lower their ideas to the range of women and to clothe reason in gallantry, can devote themselves to grave and serious discourse without fear of ridicule" (portion also cited in Claire Moses, French Feminism in the Nineteenth Century [Albany, NY, 1984], 4). As Suzanne Desan also notes, not all of Rousseau's disciples followed his views on women; his influence with respect to gender was "markedly uneven and malleable. Moralists and activists often appropriated some of Rousseau's ideas and rejected others" ("The Politics of Intimacy: Marriage and Citizenship in the French Revolution," in Women, Gender, and Enlightenment, ed. Sarah Knott and Barbara Taylor [New York, 2005], 640).

${ }^{23}$ Berthe, ed., "Réponse de Maximilien de Robespierre," 275, 278. On the depth of Robespierre's commitment to natural rights, see esp. Marisa Linton, "Robespierre"s Political Principles," in Robespierre, ed. Colin Haydon and William Doyle (New York, 1999), 37-53. 
tions were clear. It was nothing but prejudice that excluded women; they deserved the same rights as men to cultivate their intelligence; society would benefit from their inclusion.

Robespierre's position is even more remarkable when we realize that men who used gallant language in similar debates generally did so to argue the reverse. For instance, during the Academy of the Ricovrati's celebrated 1723 debate on whether women should be allowed to pursue the sciences and liberal arts, language about women's delightful qualities was used to argue for their exclusion. Giovanni Antonio Volpi, a prominent classicist, praised women as "lovable creatures" but argued that learning would "swell and muddle" their heads, making them "offensive through ostentatious bearing and manners." In Spain in 1786, the year before the Arras debate, the Madrid Royal Economic Society had taken the groundbreaking step of voting on whether to admit women and had decided to allow women members. Using gallant language, however, the members of that academy insisted that the women members must not meet with the men and that they could only be part of an auxiliary body. One member claimed that women would not want to come to the regular academy meetings because their "prudence" and "delicate virtue" would not permit them to mix with men in public; another insisted that women did not belong in the public sphere and should have separate meetings in women's homes. ${ }^{24}$

The unconventionality of Robespierre's position becomes even more evident when we examine the reaction to his discourse. Dubois de Fosseux was so elated when he read Robespierre's response that he sought to publicize it around the kingdom. Along with Kéralio's discourse, Dubois had it printed as an "excerpl" from the academy's recent meeting, and he distributed copies to other academies, government officials, and intellectuals. At least three newspapers included reports on the speech-the Journal d'histoire naturelle, the Journal littéraire de Nancy, and the Nouvelles de la république des lettres et des arts. 25

Dubois also saw the speech as striking enough to use as the basis for one

${ }^{24}$ Rebecca Marie Messbarger and Paula Findlen, eds., The Contest for Knowledge: Debates over Women's Learning in Eighteenth-Century Italy (Chicago, 2005), 92; and Theresa Ann Smith, The Emerging Female Cirizen: Gender and Enlightenment in Spain (Berkeley. 2006), esp. 91-95.

${ }_{25}^{5}$ Dubois de Fosscux published Kéralio's discours de réception, along with the short version of Robespicre's responsc, as Extrail des deux séances publiques (cited in $\mathrm{n}$. 15 above: ADPC, cote provisoire $32 \mathrm{~J} 317$ ). A sample recipient was the intendant of Rouen. The short version of Robespierre's speech published in this Extrait wals reprinted in La nature considérée sous ses différens aspects, ou Journal d'histoire naturelle 3 (1787): 417-20, and brief reports on it appeared in Nouvelles de la république dés lenters ét des arts, 28 août 1787, t. 8, no. 35, 398, and Journal linéraire de Nancy, 1. 22, 176-78 (BN, cote 8-LC9-90 [BIS]). 
of the Arras Academy's earliest collectives. Collectives were one of the academy's innovations: Dubois, whom Berthe has called a father of public opinion, would circulate essays, speeches, or questions to a wide group of correspondents in the kingdom to create a virtual space for discussion. The speech hit a nerve; according to Berthe, out of a sample of eleven correspondents, nine opposed Robespierre's position and two favored it. ${ }^{26}$ Those who opposed Robespierre viewed him as supporting a drastic change in women's position in society, while the two who praised him voiced strong sentiments in favor of women's equality. Those who read the speech portrayed it as on the cutting edge of gender issues, whether for good or ill. ${ }^{27}$

Perhaps because he deployed conventional images of women's difference, some of those who opposed Robespierre's position praised him for what they called the "seductiveness" of his argument; they insisted that his manner of arguing had almost convinced them of the rightness of his position. JeanJacques Antoine Nogent (b. 1745), the holder of a seigniorial office from the Yonne, wrote that Robespierre "seduced" and "almost converted me." The abbé Jacques Raux (a priest from Châteaudun who would be guillotined in 1794) noted that "reading the discourse of $M$. de Robespierre gave me much pleasure. This speech, though its style is slightly diffuse, is extremely seductive." Many of the writers who contested Robespierre's views even praised the

\footnotetext{
${ }^{26}$ As explained in $n .5$ above, scholars essentially may only request documents that Berthe cited after accessing the collection in its earlier home at the château de Fosseux. Though he stated that there were eleven responses in the collective (Berthe, "Un inédit de Robespierre," 270), I could only consult the eight he named, six of the nine against Robespierre's position (Lafont de Cujula, Henriquez, abbé Roux, Nogent, Dumont de Courset, and Guyetant) and both of the two for it (Michel de Sacy and Dom Grappin). While it would be valuable for another scholar to identify the remaining three letters against Robespierre if access conditions change, I do not anticipate that the arguments used in them would differ from those discussed here.

${ }^{27}$ To avoid repetition in the notes for the following paragraphs, I am providing here the citations for the eight letters I was able to consult, all housed in the ADPC, fonds Dubois de Fosseux: Nogent to Dubois, August 9, 1788 (cote provisoire 32 J 348); abbé Ralux to Dubois, June 24, 1788 (cote provisoire 32 J 352); Guyetant to Dubois, Scptember 29, 1788 (cote provisoire 32 J 343); Lafont du Cujula to Dubois, October 23, 1787 (cote provisoire 32 J 344); Dumont de Courset to Dubois, Maly 23, 1788 (cote provisoire $32 \mathrm{~J} 34$ I); Henriquez to Dubois, May 23, 1788 (cote provisoire $32 \mathrm{~J} 343$ ); Michel de Sicy to Dubois, August 17, 1787 (cote provisoire 32 J 355); Dom Grappin to Dubois, December 16, 1787 (cote provisoire $32 \mathrm{~J} 342$ ). All analyses of these letters are my own, except for thal of Henriquez. Henriquez's handwriting is so difficult that even the archivists were unwilling to affirm that to be the author's name; they designated il "Henriquez: nom ì controller" (provisionally accepting Berthe's attribution but without feeling sure of it). I defer to Berthe's deciphering powers for the one quotation I offer below from "Henriquez," provided by Berthe in "Un inédit de Robespierre," 269. All biographical information on these letter writers (excepting Sacy and Grappin) comes from Berthe's Dictionnaire des correspondants.
} 


\section{Sepinwall}

election of Mlle de Kéralio, granting her the deference due to someone of her noble birth and especially to the daughter of the well-respected intellectual Louis-Félix Guynement de Kéralio. As Jean-François Guyetant (1746-1816), a doctor from the Jura, wrote, "The discourse of Mlle de Kéralio would alone justify the decision of the Academy, if she did not have other claims to it. ... Academies need not fear compromising themselves when they make choices as generally applauded as that of Mlle de Kéralio must be." The abbé Raux noted that he had "read and reread" Mlle de Kéralio's discourse with the "greatest satisfaction." 28 Such language mirrored the traditional differentiation made between exceptional elite women and the mass of women, even among many supporters of women's learning. One general opponent of the admission of women even praised LeMasson-LeGolft's election, though she lacked Kéralio's noble pedigree, noting the pleasure he had received from reading some of her correspondence with the academy.

Nevertheless, neither the speech's use of ideas of complementarity nor the achievements and lineage of Mlle de Kéralio were enough for these writers to overlook what they saw as the dangerous implications of Robespierre's argument. Georges-Louis-Marie Dumont de Courset (1746-1824), a gentleman agronomist from the Artois region, told Dubois that "I am irritated that you do not share my view on the admission of women to academies. You do not want to recognize the larger consequences [of Robespierre's and your argument]." Guyetant wrote that while Robespierre had "defended the cause of women very well, his eloquence did not persuade me. I would not in general care to see that women pursue the beaux arts or literature." CharlesMarie de Lafont de Cujula (1749-1811), a notable from Agen who would later become a deputy to the Legislative Assembly, praised Mlle LeMassonLeGolft but declared that "il is hardly possible that women will bury themselves in abstract and difficulı sciences." For the abhé Raux, Robespierre had "unabashedly defended the cause of women, but in regard to their admission to academies, I believe that many persons will not think as he does."

On what grounds did these writers see Robespierre's views as so objectionable? Given the arguments that would be made during the Revolution and in the nineteenth century for excluding women from public discussions, one would expect declarations that women were naturally incapable of scholarly activity. Some writers did express such views. Jean Henriquez (a judicial

28 The summary of Kéralio's discourse that appeared in Extrait des deux séances, 12-14, was reprinted by Berthe in "Un inédit de Robespierre," 266-67. The discourse outlined her plan for a "general history of the customs of man and the progress of his knowledge," from the ancient to the modern world. Though even Robespierre's critics lauded the discourse, Berthe's own editorial comments on it were somewhat harsh; he called it "mediocre" and dismissed it as little better than a school essaly, even as he suggested that her father may have written it for her.

This content downloaded from 144.037.178.082 on April 03.2017 13:09:29 PM All use subject to University of (hicago Press Terms and (onditions (hup://www jounals.uchicago.edu/t-and-c). 
officer from Lorraine, 1728-94) argued that women did not have the "vigorous constitution" necessary for the study of the sciences. Lafont du Cujula invoked women's weakness and the "delicacy of their sensibilities," which made them incapable of serious work in the sciences; he saw conversation as a more appropriate domain for them. The abbé Raux claimed that the "weakness of their constitution" would not permit them to pursue sustained research.

These occasional appeals to nature, however, were dwarfed by a discourse of social utility. Lieselotte Steinbrugge has suggested that the late eighteenth century marked the ascendance of a biological discourse (popularized by Pierre Roussel) that viewed women as defined hy their sex organs and intellectually inferior to men. ${ }^{29}$ The letters in Dubois's survey imply that such ideas were not yet pervasive and that the arguments of Poullain de la Barre and subsequent Cartesians had in fact convinced many intellectuals that women's capacities equaled men's. Indeed, very few of the writers against Robespierre's position made claims about women's nature, and most agreed that women were capable of higher learning. Guyetant wrote: "I am persuaded, as Monsieur de Robespierre is, that women are capable of all types of learning, and that no branch of science is above their abilities." Lafont de Cujula conceded that "nature [had] not denied women the aptitude" for the sciences. Nevertheless, the writers insisted, women should not try to achieve great things in the world of letlers. They invoked the social disorder that would be produced not merely by women's integration into academies but also by their very pursuit of knowledge. Their arguments echoed those of eighteenth-century Italian thinkers who, in Luciano Guerci's words, believed that women "sono capaci, ma non devono": they can, but they shouldn't. ${ }^{30}$

One recurring element in arguments against women's admission to academies concerned their social roles as wives and mothers. Dumont de Courset asked Dubois de Fosseux how he would feel "if Mme. de Fosseux, instead of raising her children and molding their character ... had her head bent over a book of metaphysics ... and neglected those duties so tender and sweet to fulfill." Guyetant claimed that "nature destined women to more elevated and noble functions [than being intellectuals]. They are charged with the honorable task of giving citizens to the patrie, of raising them, of taking care of them from their first days." Giving women a taste of the world of ideas would make housework seem boring to them: "She must overcome the disgusting parts and

\footnotetext{
29) See Lieselotte Steinbrugge. The Moral Sex: Woman's Nature in the French Enlightenment, trans. Pamelal E. Selwyn (New York, 1995), esp. chap. 3.

${ }^{30}$ Guerci quotation from Messbarger and Findlen, The Contesl for Knowledge, 12. On eighteenth-century views of the difference between male and female virtue, see also Marisa Linton, "Virtue Rewarded? Women and the Politics of Virtue in Eighteenth-Century France." pts. I and I1, History of European Ideas 26, no. I (2000): $35-49$ and $51-65$.
} 


\section{Sepinwall}

monotony of domestic work. When a mother understands her duties and fulfills them, time passes quickly... . One must truly fear that a taste for belles lettres would be a damaging distraction to the interests of the household." For the abbé Raux, "If women, whose desires are passionate to begin with, decide to try to outdo each other and become scholars in order to be accepted into academies ... . what chaos will ensue inside their homes!"

Second, the academy correspondents charged, women who became intellectuals would turn into monstrosities. They would become less attractive beings, robbed of their womanly modesty. For Nogent, "I admire a learned woman, but I would rather she be someone else's wife instead of my own." For Lafont du Cujula, "A learned woman will never please anybody because she is learned; she will revolt us, and her knowledge will make her haughty. If she is both learned and modest, ... she will please us not because she is learned but because she is modest. Modesty is a virtue that man requires of this sex.... The sciences cannot increase women's ability to please; instead they threaten to make women annoying to men."

Finally, the writers charged, women would ruin academies by turning discussions from serious matters to frivolous ones. For Guyetant, "when women are admitted, seriousness will disappear. No longer will anything be discussed but pleasant trifles; meetings will consist of compliments; inane gallantry will take the place of healthy critique; and in the sanctuary of the beaux arts one will speak le langage des toilettes." Robespierre's position had been the reverse: seriousness would increase when women joined academies. Pointing to a falloff in attendance at academy sessions, Robespierre felt it was because men sought to avoid single-sex gatherings. Including women would not only lead men to attend more regularly; it would also turn women's interests from trivial to weighty subjects. In his view, integrating women would thus speed the progress of Enlightenment by returning academies to relevancy. ${ }^{31}$

Despite these writers' opposition to Robespierre's speech, he was hardly alone in pushing for women's integration into academies. He certainly had the enthusiastic support of Dubois, the powerful sécretcire perpétuel who was working to engineer the more systematic integration of women into the scholarly world. He also had the backing of the many members of the Arras Academy who endorsed Dubois's proposal and cast their ballots for LeMasson-LeGolft and Kéralio. His position was applauded as well by two

${ }^{31}$ Berthe, ed., "Réponse de Maximilien de Robespierre," 277-78 ("Academic fervor often cools. . . A type of lethargy seems to attach itself to this type of body": "Open academies to women, and you will at the same time banish the negligence and laziness which have plagued them. ... You will see the rekindling of the fire of useful emulation. ... No longer will we see genius bored to death in the Academy's armchairs"). 
correspondents in the collective, Michel de Sacy from Paris and Dom PierrePhilippe Grappin from Besançon. Sacy (1746-94) is a fascinating character about whom too little has been written. A royal censor, secretary to the minister Vergennes, and minor character among the encyclopedists, he would later become a Conventionnel. He saw Robespierre's speech as pathbreaking, expressing a sentiment that had never before been declared so forthrightly and courageously:

I strongly share the view of M. Robespierre. ... He treated a new subject, he discussed it almost impromptu, yet he treated it as if he had thought about it for years. He destroyed with a single blow an ancient prejudice which has not yet been attacked. If women have produced so many excellent works, without having had any rallying point, any academic home where their minds could develop, how many masterworks could they have birthed if, from the creation of the academy system, they were included! The volume of our good books would have been double what it is. ... Do you think that nature produced but a single du Châtelet? I am persuaded that it made many more, but that their talents have been smothered in the virtual exile to which scholars have condemned them.

Dom Grappin (1738-1833), a future member of the constitutional clergy and himself one of the honoraries elected with Kéralio and LeMassonLeGolft, was no less an enthusiast of Robespierre's ideas. Telling Dubois that he had long been "one of M. Robespierre's boosters," Grappin wrote that "I therefore think with robust conviction that what this worthy writer said is true, and that his manner of writing will attract those who had been unbelievers" to this cause. Grappin commented that Robespierre's view was becoming more widespread and that "academies are beginning to occupy themselves with the issue of women." 32

The academy's position also had the support of one of Dubois's more illustrious correspondents, the future revolutionary François-Noël (Gracchus) Babeuf. While Babeuf does not appear to have participated in the collective itself, he strongly championed the idea of women's intellectual equality in a draft letter to Dubois in 1786, contending that "there is no capability belong-

32 See Michel de Sacy to Dubois, August 17, 1787 (ADPC, cote provisoire 32 J 355); Dom Grappin to Dubois, December 16, 1787 (ADPC, cote provisoire 32 J 342). On Sacy, see esp. Berthe, Dictionnaire des correspondants, 188, and "De Sacy, Claude-Louis-Michel," in August Kuscínskí, Dictiomnaire des comventiomels (Paris, 1916), 199-200. Sacy is also discussed numerous times in Berthe, Dubois de Fosseur, since he was one of the most enthusiastic supporters of Dubois's burear de correspondance. On Grappin, see esp. Bemard Plongeron, ed., Dom Groppin [Pierre Philippe Grappin, 1738-1833] correspondant de l'abbé Grégoire (1796-1830) (Parris. 1969). Sacy's comment on Robespierre's speech is particularly apt since Robespierre wrote it in two days (Berthe, "Un inédit de Robespierre," 267). 
ing to man that is not also possessed by woman." ${ }^{33}$ Babeuf also supported admitting women to academies in a letter he sent Dubois early in 1787, and he praised Kéralio and LeMasson-LeGolft after their election. ${ }^{34}$ According to one scholar, corresponding with Dubois was in fact "the major intellectual influence on the young Babeuf." 35

Greater opportunities for women were hardly advocated only by Dubois's correspondents: Grappin's statement that the issue was extremely current in the literary world in 1787 appears to be correct. Indeed, though Arras was a center of the movement to integrate women into the republic of letters, it was not an isolated case; as I have suggested, such a movement seems to have been coalescing in 1787. This effort had precedents outside the academies. In freemasonry, as Margaret Jacob has shown, many lodges took egalitarianism to the point of admitting members without regard not only to religion or class but also to gender. The new sciences such as physics and astronomy were often taught in public settings to mixed audiences, while the musées (popular societies for discussing science) chronicled by Michael Lynn also sometimes integrated women. Indeed, Lynn has found that while some musées were closed to women, 10-20 percent of the membership of the Musée de Monsieur (France's largest musée) was female. ${ }^{36}$

${ }^{33}$ Draft from Babeuf to Dubois de Fosseux, June 1, 1786, reprinted in Oeuvres de Babeuf, ed. V. M. Dalin et al. (Paris, 1977), 1:79-118.

${ }^{34}$ Babeuf to Dubois de Fosseux, January 24 and February 24, 1787, in Corresponclance de Babeuf avec l'Académie d'Arras (1785-1788), ed. Marcel Reinhard (Paris, 1961), 55-56 and 63-64. Babeuf's only hesitation about admitting women was whether traditionalist academicians would use their presence as an excuse to avoid discussing controversial issues (Dubois de Fosseux to Babeuf, January 18, 1787, in ibid., 54-55). A conference abstract by Gauthier ("Les femmes dans l'espace public: L'idée d'une galanterie démocratique chez Robespierre," at http://revolution-francaise. net/2008/(04/I2/228-colloque-republicanismes-droit-naturel) suggests that Babeuf participated directly in the collective. These letters do not, however, indicate that Babeuf ever received Robespierre's speech (which was not written until April 1787) nor that he commented directly on it. Ian Birchall implies that Babeuf's support for women's equality was written after receiving Robespierre's speech (Birchall, "Babeuf and the Oppression of Women," British Journal for Eighteenth-Century Studies 20, no. 1 [1997]: 66). However, the letter to which Birchall is referring (the June 1786 draft cited in n. 33 above) predates the speech and the academy's admission of women by at year: Birchall seems to be confusing Robespierre's April 1787 discourse on women with his April 1786 discourse on bastards (which is in fact discussed in Babeuf's June 1786 letter, 102-4)

3is Birchall, "Babeuf and the Oppression of Women," 66.

36. Margaret C. Jacob, Living the Enlightennent: Freenasonry and Politics in Eighleenh-Centurn Europe (New York, 1991), esp. chap. 5; Michael R. Lynn, Popular Sicience and Public Opinion in Eighteenth-Cenury France (New York, 2006), esp. 46-47, 75-89. Lynn explains that the Musée de Monsieur's founder, Pilâtre de Rozicr, was particularly supportive of women learning science, believing that it 
Certain academies and academicians also had begun reconsidering women's capabilities in the years before 1787. The idea of making academies coeducational had received the support of individual thinkers such as D'Alembert, and some women had been admitted to provincial academies in France and to more established ones in Italy. Berthe argues that a movement in favor of women was created in Dijon in 1762 after the abbé Picardet presented an essay arguing that "women are as suitable as men for the study of the sciences and arts," though that academy did not go so far as to admit women members. In 1777, the Besançon Academy held a contest on whether improved education for women could help make men better. And, in 1782, the small but influential academy of Châlons-sur-Marne asked how to improve women's education. One respondent was the future Jacobin Jean-François Dumas, who agreed that women's capabilities were equal to men's and that their virtue could increase if they were educated. ${ }^{37}$ Londa Schiebinger has also suggested that an unofficial women's academy may have been created in France in 1772, though its members had to defend its existence. ${ }^{38}$

These general discussions about women - and analogous ones outside France-made it possible in the 1780 s for a growing number of academies to feel comfortable incorporating women. A women's scientific society was founded in the Netherlands (1785) and the Madrid Economic Society created an auxiliary for women (1786). ${ }^{39}$ For France, while more systematic work needs to be done on identifying women academy members, I estimate a tripling in the number of French académiciennes in this period. Nîmes elected a woman in 1782 (Mme de Bourdic); Lyon elected one woman in 1782 and

demonstrated "every day the progress of our century" (89). On the musées and women, see also Dena Goodman, The Republic of Letters: A Cultural History of the French Enlightenmen' (Ithaci, NY, 1994), 259-71.

${ }^{37}$ Roland G. Bonnel and Catherine Rubinger, "Introduction," in Femmes savantes et fenmes d'esprit: Women Intellectuals of the French Eighteenth Century, ed. Bonnel and Rubinger (New York, 1997), 20-21, 24-26; Berthe, "Un inédit de Robespierre," 27()$-71$. While there was no formal network connecting academies across Europe, developments such ats the election of Madame de Châtelet to Italian academies were well known to aciademicians in France, both via personal correspondence between intellectuals and because of newspaper reports. The Nowrelles de la république des letrres et des arts, which began publishing in France after 1777, made reporting on academic events across the continent even more regular. On Dumas's essaly, see Linton, "Virtue Rewarded?" pt. II, 57.

3. Schiebinger, The Mind Has No Sex, 35. Schiebinger found lectures by the alcaldemy's founder, a woman who called herself Philothée, but she remained unsure whether the academy was "real or imaginary."

39 Margaret Jacob and Dorothée Sturkenboom, "A Women's Scientific Society in the West: The Late Eighteenth Century Assimilation of Science," Isis 94 (2003): 217-52: Smith, Emerging Female Citizen, chaps. 3 and 4. 
another in 1788 (Fanny de Beauharnais, then Victoire Lalliée); and Béziers elected a woman in 1788 (Nicole Lepaute). Arras added its third woman member in 1789 (Mlle de Chatellier). ${ }^{40}$ And early that summer, just before switching to revolutionary developments, the Arras Academy began a major collective (one of its innovative discussions circulated by letter) on Quelle est la science la plus utile aux femmes? (Which branch of knowledge is most useful to women?). This survey went to 182 correspondents, larger than any to date except for one on the Estates-General. ${ }^{41}$

Meanwhile, an increasing number of publications in this era-including two important ones by women in 1787-questioned existing gender conventions, as Karen Offen and Claire Moses have shown. ${ }^{42}$ And the same year, women's intellectual capacities were recognized from the pinnacle of France's academic system. In 1787, Condorcet wrote his Lettres d'un Bourgeois de New Haven. The essay argued that women's bodies disqualified them from jobs like being soldiers, but that other differences between the sexes were "the result of education" rather than nature. Citing Voltaire, who had "granted them every talent except invention," Condorcet intimated that the smartest women should be no less eligible for academies than many men already in them. ${ }^{43}$ At this time, Condorcet was not simply a well-respected mathematician and aristocrat but also held perhaps the most prestigious position in

${ }^{40}$ See Bouillier, L'Institut et les académies de province, 85; Berthe, "Un inédit de Robespierre," 271-72; and Schiebinger, The Mind Has No Sex, 30. Counting Bocage, Kéralio, LeMasson-LeGolft, and four women named maîtresses of the Académie des Jeux Floraux, Roche states that there were "less than ten or so women in the whole century who were académiciennes" (Le siècle des lumières en province, 1:193-94, II:63 n. 33). Though I believe he is undercounting, I am drawing the idea of tripling from this number, with Bocage and the two maîtresses from Jeux Floraux for the pre-1780s period, compared to the seven women I have identified for the 1780 s plus two named maîtresses by Jeux Floraux in this decade. The maîtrise of the Académie des Jeux Floraux was not fully equivalent to being an académicierne, but was a title bestowed on anyone who won three of that academy's prize competitions. Caradonna identified at least one more woman who was named a matîresse in the eighteenth century but does not appear in Roche: Mlle Charlotte de Bermann (Caradonna, "The Enlightenment in Question," in chap. 3, App. A).

4) See Berthe, Dubois de Fosseux, 416: and Berthe, "Réponse de Maximilien de Robespierre," 276 п. 7. Berthe's works offer only a few details about this survey. In Dubois de Fosseux he notes that Sácy was the tirst respondent. on June 22, 1789; in the latter article, he explains that "the valst majority of the approximately ninety correspondents ... who responded to the question in 1789-1790 ... agreed with Robespierre that history and morality were the two disciplines that were most suited for women. But rare were those who also encouraged women [as Robespierre had] to "gather the flowers of literature."

42 See Karen M. Offen, European Feminisms, 1700-1950: A Political History (Stanford, CA, 2000), chap. 2: and Moses, French Feminism, 9.

1.3 Jean-Antoine-Nicolas de Caritat Condorcet, "Lettres d'un bourgeois de New 
France's royal academy structure: sécretaire perpétuel of the Académie des sciences. It has been suggested that because of his elevated position in society he was able to advance a position that might have drawn derision to others. ${ }^{44}$

Clearly, this was a moment when views of gender-particularly those related to the mind-were being called into question. The late eighteenth century was thus hardly a time when intellectuals unreflexively shared the views that Amar would express during the Revolution: on the contrary, support for women's intellectual capacities had reached the point where Robespierre's opponents in the Arras collective barely dared suggest that women were incapable of learning. Given the examples of accomplished women scholars such as Mlles de Kéralio and LeMasson-LeGolft, along with the diffusion of Cartesianism, this position might have been seen as laughable. For the most part, those seeking to prevent women's advances avoided arguments about women's nature and instead made claims about what women's social roles should be. With the Arras decision a fait accompli, however, and one defended so adeptly by one of the kingdom's most talented young lawyers, this group found itself on the defensive. As Roche has noted, the official equality of the academies meant that what one decided affected the others. ${ }^{45}$ Once academies like Arras voted to admit women, académiciennes entered the national network and were due the respect of other academy members nationwide.

The Arras debate, along with the larger discussions to which it belonged, thus help us revise our understanding of gender in the late Old Regime. Scholars such as Steinbrugge and Thomas Laqueur have suggested that biomedical understandings of gender had become dominant among intellectuals by the end of the eighteenth century. ${ }^{46}$ As the debate over Robespierre's speech makes clear, however, Cartesian thinking about men's and women's equality remained strong through the 1780s. The changes in Arras and other academies also show that by 1787 the public sphere was not contracting to exclude learned women but opening to include them. Indeed, even as salons

Haven à un citoyen de Virginie [1787]," in Oetures de Condorcet, ed. O'Connor and Arago (1847), 9:3-93 (esp. 18-19).

${ }^{44}$ See Constance Row, "The Present-Daly Relevance of Condorcet," in Condorcet Studies I, ed. Leonora Cohen Rosenfield (Allantic Highlands, NJ, 1984), 24. Still, Madelyn Gutwirth notes that even Condoreet was forced to retreat from some of his arguments about women after the "stubborn, intimidating silence that greeted his invitation to others to debate his proposals" (Gutwirth, The Twilighl of the Goddesses: Women and Representation in the French Revolutionary Era [New Brunswick, NJ, 1992], 203).

15 Roche, Le siecle des limieress en province, 1:74.

${ }^{40}$ See Steinbrugge, The Moral Sex, und Thomals W. Larqueur, Making Sex: Body and Gender from the Greeks to Freud (Cambridge, MA, 1992). 


\section{Sepinwall}

were being eclipsed as preeminent intellectual institutions, as Dena Goodman has indicated, ${ }^{47}$ women were not necessarily shunted to the periphery of the republic of letters. On the contrary, new developments promised advances for them-that they might be accepted as intellectuals in their own right, not merely valued as mediators or civilizers of men.

The Arras debates also shed important new light on the Revolution's gender politics. The Revolution is often spoken of as a moment when customary views were subjected to scrutiny and suddenly made to seem old-fashioned by the new light of revolutionary universalism. As we have seen, however, the nature of women's capabilities was already holly contested by 1789 , including by Robespierre himself. As Siep Stuurman has written about the earlier debates on women in the eighteenth century, "male authority could no longer be taken for granted; it had to be argued for-or, of course, against." 48 The convention's policies on issues such as women's political clubs thus represent not a continuation of views on gender that were obvious to men of the eighteenth century, but an effort to reverse women's advances and deem their maternal roles paramount.

How then might we explain the triumph of these policies? For one thing, as numerous historians of gender and the Revolution have made clear, the banning of women's political clubs was a contingent reaction arising from particular revolutionary circumstances. Its immediate impetus was a dispute between two groups of women-market women and the Sociely of Revolutionary Republican Women-over the issues of price controls and whether women should be obliged to wear revolutionary symbols such as cockades and liberty caps. After brawls erupted between the two groups in the fall of 1793, market women demanded the closing of the Society of Revolutionary Republican Women. The National Convention responded on October 30, 1793, by outlawing women's clubs outright.

Scholars have suggested that the Jacobins felt threatened by the sociely because its members were pushing for an economic policy that the Jacobins did not wish to enforce, so that the decision was made more out of a desire to neutralize the society than for purely ideological reasons. ${ }^{+1}$ Nevertheless, to

${ }^{47}$ See Goodman, The Republic of Lelters, chap. 6.

${ }^{48}$ Stuurman, François Poulain de la Barre, 19.

49 See esp. Levy and Applewhite, "Women and Militant Citizenship in Revolutionary Paris"; Olwen Hufton, Women and the Limits of Citi-enship in the French Revolution (Toronto, 1992), esp. chap. 1: Shanti Maric Singham, "Betwixt Caltle and Men: Jews, Blacks, and Women, and the Declaration of the Rights of Man," in The French Idea of Freedom: The Old Regime and the Declaration of Righs of 1789, ed. Dale Van Kley (Stanford, CA, 1994), 114-53; and Dominicue Godincau, The Women of Paris and Their French Revolution, trans. Katherine Streip (Berkeley, 1998). On how the choice of "regeneration" as a program for the Revolution also worked against women's inclusion, see Alyssa Goldstein Sepinwall. The Abbe Grégosire and the 
note the circumstances of 1793 does not fully explain why Amar's absolutist terms were accepted by the Convention. The disintegration of their potential counterweight, the Cartesian feminism earlier espoused by Robespierre, still requires explanation. In fact, the movement to increase opportunities for women hardly disappeared in the transition from Old Regime to Revolution. Successful initiatives to give women more equality in inheritance, in education, and in seeking divorce all stemmed from efforts by women and their supporters to reverse the gender-related inequalities of the Old Regime. Clubs such as the Cercle Social, which included women as members, led the efforts to eradicate women's legal disabilities. ${ }^{50}$ Their arguments rested not only on the older premises of Cartesian feminism but also on new discourses of universal rights.

The revolutionary years also witnessed new proposals for women's equality. Some of these were made by women themselves, using the language of rights to make bolder demands than they would have dared under the Old Regime. These ranged from now-famous figures such as Olympe de Gouges and Etta Palm d'Aelders to more anonymous groups such as the republican women of Beaumont, who told the Convention that "the rights of man are also ours." ${ }^{51}$ Like-minded men added their support. Beyond Condorcet's pamphlet of 1790, defenders of women's rights included Pierre Guyomar, a National Convention member from the Côtes-du-Nord department. In an April 1793 pamphlet, Guyomar employed Cartesian terms to argue for extending political rights to women. He asserted that there was no fundamental natural difference between men and women-that sexual difference was no more meaningfu] than differences of skin color. He complained that despite the Revolution's abolition of feudalism, the new order still preserved "a privileged caste, a formal aristocracy of males." Insisting that the Declaration of the Rights of Man applied to "men of both sexes" (hommes des deux sexes), Guyomar invoked Rousseau to declare that women were part of the Social Contract too. Finally, he appealed to his colleagues to "liberate women from [their] slavery" and thus "give the peoples of the universe a model of the purest democracy.". 52

French Revolution: The Making of Modern Universalism (Berkeley, 2005), esp. 97-102 and 120-23.

${ }^{50}$ See esp. Gary Kates, The Cercle Social, the Girondins, and the French Revolution (Princeton, NJ, 1985), 118-27; on female participation in other clubs, sec Godineau, The Women of Paris.

${ }^{51}$ See Godineau, The Women of Paris, 282ff., for an excellent discussion of such women.

${ }_{52}$ Pierre Marie Augustin Guyomar, Le partisan de l'égalité politique entre les individus, ou, Problème très-importan de l'égalité en droits ê de l'inégalité en fait (Paris, 1793), 2, 4, 6, 18, 14, 20. A lesser-known project extending citizenship rights to 


\section{Sepinwall}

On the floor of the Convention, similar principles were asserted by Gilbert Romme. Earlier in the Revolution, Romme worked closely with the "revolutionary Amazon" Anne-Joseph Théroigne de Méricourt and advocated the education of women. ${ }^{53}$ In April 1793, Romme spoke on behalf of the committee (the Comite d'analyse, also called the Commission of Six) that the Convention had appointed to plan a new version of the constitution; its other five members were Bertrand de Barère, Jean Debry, Charles Éléonor Dufriche-Valazé, Jean-Denis Lanjuinais, and Louis-Sebastien Mercier. Reporting for the others, Romme declared that women had an equal share in the category of the rights-bearing homme ("All men have an equal right to liberty, no matter their age, sex or color"). He further insisted that all men must be free "to exercise their physical, intellectual and moral faculties in the way they themselves consider good and useful," as well as to stand for election and to vote. Though at least one of the other committee members (Lanjuinais) dissented from that part of the report, the Archives parlementaires reports that at the conclusion of Romme's speech, a "large number of members" shouted "Print it, print it!" While the committee's report did not focus only on women, members' enthusiasm indicates that they, at the very least, found this aspect of the committee's report unworthy of serious objection..$^{54}$

certain women was made on April 18, 1793, by J.-M. Rouzet (see http://www.assembleenationale.fr/histoire/femmes/citoyennete_politique_revolution.asp). On other littlediscussed aspects of the debates conceming women, see esp. Serge Aberdam, "Deux occasions de participation féminine en 1793: Le vote sur la Constitution et le partage des biens communaux, "Annales historiques de la révolution française, no. 339 (2005): 17-34.

${ }^{53}$ On Romme's activities with Théroigne de Méricourt in the mixed-gender Société des Amis de la Loi, see A. Galante Garrone, "Gilbert Romme et les débuts de la Socićté des "Amis de la Loi," in Gilbert Romme (1750-1795) et son temps, acles du colloque tenu à Riom et Clermont, les 10 et II juin 1965 (Paris, 1966), 98-111. On it December 1792 report by Romme urging improved education for women, including cocducation in primary schooling, see M. J. Guillaume, ed., Procès-verbanx du Comité d'instruction publique de la Convention nationale (Paris, 1891-1907), 1:201-20, esp. 207 and 214. Romme seems to have emerged from a similar milieu ats many of the pro-women figures in the Arras debate; his mentor, a Russian aristocrat living in Paris. wals a follower of Roussealu who nevertheless advocated equal education for girls ( $\mathrm{sec}$ A. Galante Garrone, Gilbert Romme, histoire d'un révolutionnaire, 1750-1795 [Paris, 1971]. 59ff.).

${ }^{54}$ See Gilbert Romme, "Rapport fait au nom du Comité d'analyse sur des différents projets de déclarations des droits envoyés à cette commission, avec un projel de déclaration des droits," in AP 62:263-69. The final section of the report. including the articles discussed here, was indeed published by the Convention as Convemion nationale: Troisieme partie du rapport fait au nom de la Commission des six, par $G$. Romme, sur la déclaration des droits, dans la séance du 17 avril 1793. I'an 2 de la République (Paris, 1793). On Lanjuinais's hesitation about the part of the report 
Despite Guyomar and Romme's entreaties, the constitution passed in June 1793 failed to specify that women were equal "hommes"; the October 1793 decree went even further, specifically stripping women of a key civic right. Some prominent scholars of gender and the Revolution have attributed the failure of the ideas presented by Guyomar and Romme to their being alone in their convictions. In Dominique Godineau's view, "for the overwhelming majority of deputies, the question did not even exist"; the deputies "did not even consider challenging the relations that existed between women and men," except on divorce. Elizabeth Badinter similarly presents Romme's speech as one offered personally by a rare individual. ${ }^{55}$

On the one hand, such a view ignores the context of Romme's report and its reception; on the other, it is at odds with what we have already seen about the contentious nature of gender issues in the prerevolution. I would argue that the acceptance of Guyomar's and Romme's positions was doomed not by their being singular in their outlooks on women, but by other factors: the way the events of summer and fall 1793 changed discussions of gender, and the total absence from these discussions of the prominent revolutionaries who in previous years had championed women's inherent equality. National Convention members such as Robespierre and Condorcet (not to mention Sacy) remained silent, both during the June 1793 discussions about whether the new constitution should include equal citizenship for women and during the October debates on women's clubs. Indeed, while more work could be done on Robespierre's individual actions in the course of revolutionary gender politics, it is clear that though he was not one of the Jacobins who most vocally opposed women's ability to participate in political life, neither did he rise to their defense. Even from his seat on the Committee of Public Safety, at the height of his power, Robespierre did not intervene to avert a blanket ban on women's ability to engage in political action. The festivals Robespierre directed during the Terror also relegated women to a secondary role. ${ }^{56} \mathrm{Had}$

granting women equal political rights, and his belief that others shared it, see his comments in AP 63 (April 29, 1793): 564.

is Godincau, The Women of Paris, 290; Elisabeth Badinter, Paroles d'hommes (1790-1793): Condorcet, Prudhomme, Guyomar (Paris, 1989), 23, 136-40ff.

5n Sce, e.g., Lynn Hunt, The Family Romance of the French Revolution (Berkeley, 1992). Robespicrre appears very little in this work, even in discussions of the "Band of Brothers," because he made fewer exclusionary pronouncements than some other Jacobins. On the other hand, as Hunt notes, "More important ... than the explicit exclusion of women from the public political sphere was the subtle reorientation taking place with respect to the role of the family and of the mother within the family. Before the end of the Terror, Robespierre and other leading Jacobins took small yet significant stcps to reinforce the virile image of the Revolution and downplay any association of women with active political roles. The choice of Hercules to replace the militant 


\section{Sepinwall}

Robespierre changed his views between 1787 and 1793? Why was the issue about which he was so passionate in 1787 not one that remained important for him?

On one level, Robespierre's reticence can be understood by recognizing that the issue of women had always been for him - as for his opponents in the Arras debale-a subsidiary component of a larger project. Indeed, both sides in 1787 had been more interested in clearing obstacles to social progress than in women's status alone. For the men who opposed Robespierre, one of France's greatest challenges in the eighteenth century was the existence of "unnatural" social women who were shirking their "natural" mothering duties. Robespierre's Old Regime opponents can be seen as part of the movement Madelyn Gutwirth chronicled when she wrote: "when Rousseau speaks, he speaks for a vast population of angry antiaristocratic male traditionalists and disaffected lovers of all classes in whom the idea of banishment of women from an active role in culture strikes a chord of deep, rancorous responsiveness." To these men, influenced by Rousseau, women's extrafamilial roles marked a perversion of sociely, one that needed to be reversed so that society could become better and more natural..$^{57}$

Robespierre, in contrast, had held an alternate view of social progress-one that might also be linked to Rousseau, but with a different emphasis. This becomes clearest when we compare Robespierre's advocacy of women's integration into academies with that of Dubois de Fosseux. Where Dubois's feminist position had centered on granting accomplished noblewomen the respect due to male members of their class, Robespierre's had rested on the idea that doing so would henefit the public good. Though Dubois altered Robespierre's phrasing in the version of the speech that he published, Robespierre had directed Dubois to say that his speech sought to show that "it is advantageous to admit women in literary societies and to prove that this institution will be useful to women, to academies and to the bien public." 58

goddess of Liberty on the seal of state was only the most obvious of these decisions" (153).

${ }_{57}$ See Gutwirth, The Twilight of the Goddesses, 77-78, 120ff., quote from 132; and also Mary Jacobus, "Incorruptible Milk: Breast-Feeding and the French Revolution," in Rebel Darrghters, ed. Melzer and Rabine, 54-75. On the role of new ideas of childhood in strengthening the idealization of maternity, see also Steinbrugge, The Moral Sex, 4.

${ }^{58}$ See Berthe, "Un inédit de Robespierre," 264. When he summarized Robespierre's response to Mlle de Kéralio in the acidemy’s transactions, Dubois de Fosseux wrote that Robespierre had praised someone who "had the advantage of bearing a name celebrated by great talents, and especially for the merit of her respectable father, whose memory she invokes in her discourse in a manner as noble as it is touching." Robespierre had not praised Kéralio's noble lineáge at all; in his own version of this 
Robespierre imagined a new society organized around advancing the bien public; in this case, he fell that the good of society was being impeded by those who "want to condemn all women to ignorance and frivolity." He was concerned that in their present state of exclusion, women had been tempted to "prostitute their precious encouragement by directing it towards frivolous or ridiculous things" rather than to "attach their benevolence only to worthy objects and men."

Robespierre's vaunting of the bien public was also the framework used by other Enlightenment-era proponents of expanding women's opportunities. As Theresa Ann Smith has pointed out, the Spanish intellectuals who voted to include women in the Madrid Economic Society in 1786 spoke of traditional Spanish society as having kept women idle and frivolous, thus stalling progress. As one member, Ignacio López de Ayala, had asked, would half of Spain "remain useless as up to now" or be "furnished enlightenment and knowledge in order to help men and to govern their fortunes and families with intelligence. It amounts to determining if this sex can prove useful." If women could reverse their idleness, seen as characterizing Old Spain, and become useful, Ayala and others argued, Spain could advance "toward a more enlightened future." Italians who had sought to include women in scholarly bodies had also invoked the idea of the "public good." These views were tied to an Enlightenment faith in the necessity of wiping out ignorance and spreading knowledge. ${ }^{60}$

Yet by the time the Revolution was under way, Robespierre and others operated in a system that promised many more avenues for improving the bien public than adding women to scholarly gatherings. Indeed, the academies were increasingly seen as irrelevant and would be closed that year by decree of the Convention, with none other than the abbé Grégoire, who as a young man in 1788 had been thrilled to enter into Dubois de Fosseux's correspondence network, writing the report. ${ }^{(1)}$ The Revolution brought opportunities to transform society far more fundamentally, from wiping out the monarchy to

passage, he had only applauded her "charms" and the "extent of her learning." For more on the neo-Platonic content of Dubois's views of women, see descriptions of his discourses on "women's minds" and "women's speech" in Mémoires de l'Académie d'Arras 29 (1856): 185-90.

59 Berthe, "Réponse de Maximilien de Robespierre," 275, 279-80.

"6) See Smith, Emerging Female Cinizen, 88, 96; and Messbarger and Findlen, eds., The Contest for Knowledge, 5, 122.

${ }^{61}$ See Henri Grégoire, Connention nationale: Rappont et projet de décret présentés au nom du comité d'instruction publique à la séance du 8 aô̂t 1793 (Paris, 1793). Grégoire praised the scientilic work of certain academies, but he felt that others were "gangrened with an incurable aristocracy" (4-5). On Grégoire and Dubois de Fosseux, see Berthe, "Grégoire, élève de l"abbé Lamourette," Relue du Nord 44 (1962): 39-46. 


\section{Sepinwall}

creating a new national religion. And among oppressed groups whose status might be changed, women's cause may have seemed less urgent. Indeed, I find it striking that of the men who had most enthusiastically advocated women's integration into the republic of letters in the 1780s, three were also committed abolitionists: Condorcet, Robespierre, and Sacy. The latter had written a groundbreaking abolitionist poem in 1775 and remained committed to the cause until his death in $1794 .{ }^{62}$ With a war raging in Saint-Domingue in the early 1790s, the issue of slavery loomed as more pressing to resolve in France than that of women-particularly since women intellectuals tended to be aristocrats. The attentions of the other pro-inclusion figures in the Arras debate also turned elsewhere: Grappin became absorbed by the battle between Catholic supporters and opponents of the Revolution. Meanwhile, Dubois de Fosseux, an aristocrat no matter how progressive his views, had to stay abreast of the changes and avoid arrest. At first elected mayor of Arras, he was later imprisoned and freed only because of his many friends in the Convention. ${ }^{63}$

By fall 1793, the actions of women themselves likely made Robespierre and other erstwhile proponents of women's equality even less inclined to continue championing this cause. Robespierre's feminism had, as I have noted, rested on a vision of gender complementarity that emphasized the social utility of women's charms. Robespierre had supported women's rights, but he had also assumed women's sweetness and docility. Moreover, his vision of heterosociability had relied on complementarity rather than on complete equality. The Society of Revolutionary Republican Women did not behave politely and charmingly; its members were unruly and independent. Rather than encouraging the policies of the Jacobins, their activism threatened Jacobin power. Instead of being "delicate" or "pleasing," they armed themselves with weapons. Such behavior, following on the heels of Charlotte Corday's July 1793

${ }^{62}$ Condorcet's and Robespierre's abolitionist views are too well known to require elaboration. Sacy has been largely forgotten in the history of French abolitionism. However, he wrote a pioneering abolitionist poem for the Académic française's poetry competition of 1775; though it did not win, he published it as M. de Silcy, L'esclavage des américains et des nègres: Pièce qui a concoura pour le prix de l'Académie Françoise, en 1775 (Paris, 1775). This pocm was reprinted in La Révolution française et l'abolition de l'esclavage (Paris, 1968), vol. 1, and is mentioned by David Brion Davis in The Problem of Slavery in Westem Culture (New York, 1988), 420, 423-24. Sacy's continued abolitionism is evidenced by his presenting a proposal to the Committee of Public Safety on 20 pluviôse II (Fcbruary 8, 1794) arguing that the colons be required to fund freed slaves' return to Africal (sce Kuscínskí, Dictionnaire des comentionnels, 200). Babcuf's support for women's ejuality also went hand in hand with a defense of blacks and Jews; see Birchall, "Babeuf and the Oppression of Women," 68.

${ }^{0.3}$ See Plongeron, ed., Dom Grappin; and Ghislaine Bouchet, Cinquante figures du Pas-de-Calais pendant la révolution (Dainville, 1989), 55-56. 
assassination of Marat, was likely a shock to Robespierre, as it was to many men of the time. ${ }^{64}$

Robespierre may have kept silent, therefore, not only because the women in question were threatening his faction's direction of the Revolution but also because he began to question the implications of his earlier arguments. Certainly, he was hardly the first deputy to move away from universal pronouncements after realizing their social implications. Indeed, the events of October seem to have made even Romme, whose ideas on the subject were more radical than Robespierre's, retreat from his earlier position. ${ }^{65}$ The shift by these men may have functioned in the same way as the backlash against Mary Wollstonecraft's ideas in early nineteenth-century Europe. Her arguments about women's equality had found receptive audiences until, after her death, her husband William Godwin published the details of her unconventional life, causing many male intellectuals to see feminism as leading to inappropriate behavior. ${ }^{66}$ For Robespierre, abandoning his earlier appeals to eradicate prejudice against women and instead adopting a discourse of republican motherhood may not have seemed an about-face; he may simply have felt that he was redeploying his argument that women needed to turn away from frivolous pursuits for the sake of the bien public. ${ }^{67}$ It should be emphasized that, as far as we are currently aware, Robespierre never replaced his Cartesianism with a biomedical view of women; unlike other Jacobins, he did not make generalizing pronouncements about women's innate inferiority. Still, as he moved toward a position of "they can but they shouldn't," his depictions of ideal women began to converge with those of his former opponents.

The Cartesian feminism of the late Old Regime may have had its last gasp in October 1793 when the deputy Louis-Joseph Charlier rose to challenge

\footnotetext{
${ }^{64}$ On fears of pistol-carrying women, see Godineat, The Women of Paris, 130; on the connection to Corday, see, e.g., Offen, European Feminisms, 84.

${ }^{6}$ When Amar presented his report banning women's clubs, Romme spoke up not to affirm the universality of rights but to make sure women would also be blocked from meeting secretly with troublemakers. See AP 78 (9 brumaire Il/October 20, 1793): 49 n. 2. By this point, Romme's attentions had turned to other matters; by late September, he was creating the revolutionary calendar and working toward dechristianization (see Albert Soboul, "Présentation de Gilbert Romme," in Gilbert Romme [1750-1795] et son lemps, 16ff.). On the larger fissure hetween revolutionaries' universal pronouncements and their application of rights, see, c.g., Scpinwall, The Abbé Grégoire and the French Revolution, chap. 4, and Singham, "Betwixt Cattle and Men," 114-53.

${ }^{60}$ On the reception of Wollstonecraft after Godwin's publication of her Memoirs, see, e.g., Barbara Taylor, Mary Wollstonecraft and the Feminist Imagination (New York, 2003), 27-28.

${ }^{67}$ On Robespierre's general struggles to maintain his Old Regime principles in the face of the Revolution's changing circumstances, see Linton, "Robespierre"s Political Principles."
} 


\section{Sepinwall}

Amar's ban on women's ability to assemble. "As long as you do not contest that women are part of humankind," he complained, "can you take away from them this right which is common to every thinking being?" By this point, however, Charlier's argument failed to rouse his colleagues; Amar's view became the policy of the Revolution. ${ }^{68}$

The Jacobin exclusion of women from political life was therefore not an inevilable consequence of an unreflexive chauvinism derived from widely held biomedical views of women in the Old Regime. Cartesian feminist and biological discourses competed in the Revolution as in the 1780s; the latter rose both because of contingent circumstances and because of ambivalence on the part of some of the former's proponents in the face of women's unexpected political behavior. It is also important to underline that support for Amar's arguments was not an ineluctable result of revolutionary enthusiasm for Rousseau. Olwen Hufton has explained the revolutionaries' hostility to women by noting: "If the Constituents had a view of women, ... it was straight out of Emile and the Enlightenment." ${ }^{99}$ Yet if Robespierre and others such as Babeuf were deeply influenced by Rousseau, they did not necessarily share the latter's views on gender roles. Guyomar had begun his defense of women's equality with one quotation from Jean-Jacques ("I say whatever arises in my soul, and what I believe to be the truth"), and he concluded with another drawn from the Social Contract. Rousseau had also been Romme's favorite author. ${ }^{70}$ Rousseauism could have multiple interpretations with regard to gender, and the Old Regime had left the Revolution multiple strains of thought on women. The victory of Amar's anti-Cartesian position was hardly preordained.

Nevertheless, with the changes wrought by the Revolution, the movement to expand women's place in the public sphere had collapsed by the early nineteenth century. This occurred both in France and elsewhere in Europe, as a backlash against increased opportunities for women coincided with that

${ }^{68}$ AP 78 (9 brumaire II/October 30, 1793): 51. Charlier had completed a term as president of the convention only a few weeks earlier, something that indicates an important degree of popularity. By late October, however, he stood alone on this issue.

(5) Hufton, Women and the Limits of Citizenship, 4.

71) Guyomar, Le partisan de l'égalité politique, 1, 20; Soboul, "Présentation de Gilbert Romme," 9, 17. On Babeuf's parallel departure from Rousseau on women, sec Birchall, "Babeuf and the Oppression of Women," 66. Being influenced by Rousscau yet departing from his views on gender was not unique to men of the era: Mary Wollstonecraft and other women embraced Rousseau in many ways but rejected his limiting views on gender. See, e.g., Wollstonecraft, Maria, or The Wrongs of Woman (1798; New York, 1994), 22 ("Rousseau alone, the true Prometheus of sentiment, possessed the fire of genius necessary to portray the passion, the truth of which goes so directly to the heart"), along with the many favorable and critical references to Rousseau in Vindication of the Rights of Woman. On "multiple and contradictory readings of Rousseau" on gender, see also Mary Trouille, Sexual Politics in the Enlightenment: Women Writers Read Roussean (Albany, NY, 1997). 
against revolutionary ideals more generally. ${ }^{71}$ Though the early nineteenthcentury system of "separate spheres" may have been less rigid than scholars of gender once believed, ${ }^{72}$ it is nonetheless true that in the wake of the Revolution the landscape for discussing women shifted away from the terms of the Arras debate. Medical arguments displaced Cartesianism, and it no longer seemed laughable for intellectuals to make claims about women's separate nature. Making moot the "they can but they shouldn't" discourse, arguments about women's natural intellectual inferiority became perfectly respectable. ${ }^{73}$ When Marie LeMasson-LeGolft sought admission to the reorganized academy in Rouen under Napoleon, she found herself turned awaybecause, as one member told her, "the Academy, in reforming itself five years ago, resolved to exclude women." While this member, Dom François-Philippe Gourdin, called the decision "deplorable" and assured her that "I am personally angered by it," his position had become exceptional. ${ }^{74}$ Far more influential were the views of figures like Julien-Joseph Virey and Pierre Cabanis, who argued that "in woman, the cerebral matter shares the softness of the other parts." 75 Robespierre did not have an opportunity to voice his views on this cultural shift; he, like the Arras Academy's initiative, had become a casualty of the Revolution he had played such a large role in creating.

7 On the general backlash, see Offen, European Feminisms, 74-75. On the vanjshing of women's academies in Spain, see Smith, Emerging Female Citizen, esp. 198-99; on Italians' late-eighteenth-century conversion to the idea that "an ideal scientific sociely should be a world without women," see Findlen, "Science as a Career," 467. On how the professionalization of science and its removal from the domestic sphere further excluded women around Europe, see esp. Londa Schiebinger, "Maria Winkelman at the Berlin Academy: A Turning Point for Women in Science," in History of Women in the Sciences: Readings from Isis, ed. Sally Gregory Kohlstedt (Chicago, 1999), 39-65.

${ }^{72}$ On this point, see esp. Hesse, The Other Enlightenment; and Denise Z: Davidson, France afier Revolution: Urban Life, Gender, and the New Social Order (Cambridge, $\mathrm{MA}, 2007$ ).

${ }^{73}$ On the rise of medical arguments about women's difference at the end of the century, see esp. Steinbrugge, The Moral Sex; on the use of such discourse to justify excluding women from citizenship, see also Hunt, The Family Romance of the French Revolution, 203.

${ }^{74}$ See Gourdin to LeMasson-LeGolft, August 15, 1809, in BMR, ms. 119 ["876"]). Aside from a few localities (see Davidson, France after Revoluton, 143; and Edmond Reboul, Regards sur l'Académie des sciences, belles-leares et arts de Lyon [Nîmes. 19911, 131), Rouen's decision was replicated nationally, and women were no longer included as members in reorganized academies, whether because of explicit decisions or tacit ones. On the unspoken and fragmented quality of women's intellectual exclusion in the early nineteenth century, see Geneviève Fraisse, Reason's Murse: Serral Difference and the Birth of Democracy' (Chicago, 1994), esp. 59 and 170-71.

${ }^{75}$ Cabanis, Relations Between the Physical and Moral (1802), cited in Fraisse, Reason's Musse, 85. 